\title{
Trump's pick for environment agency chief sued government over climate rules
}

\author{
Oklahoma attorney-general Scott Pruitt has sought to reverse federal limits on greenhouse-gas emissions and air \\ pollution.
}

Jeff Tollefson

07 December 2016

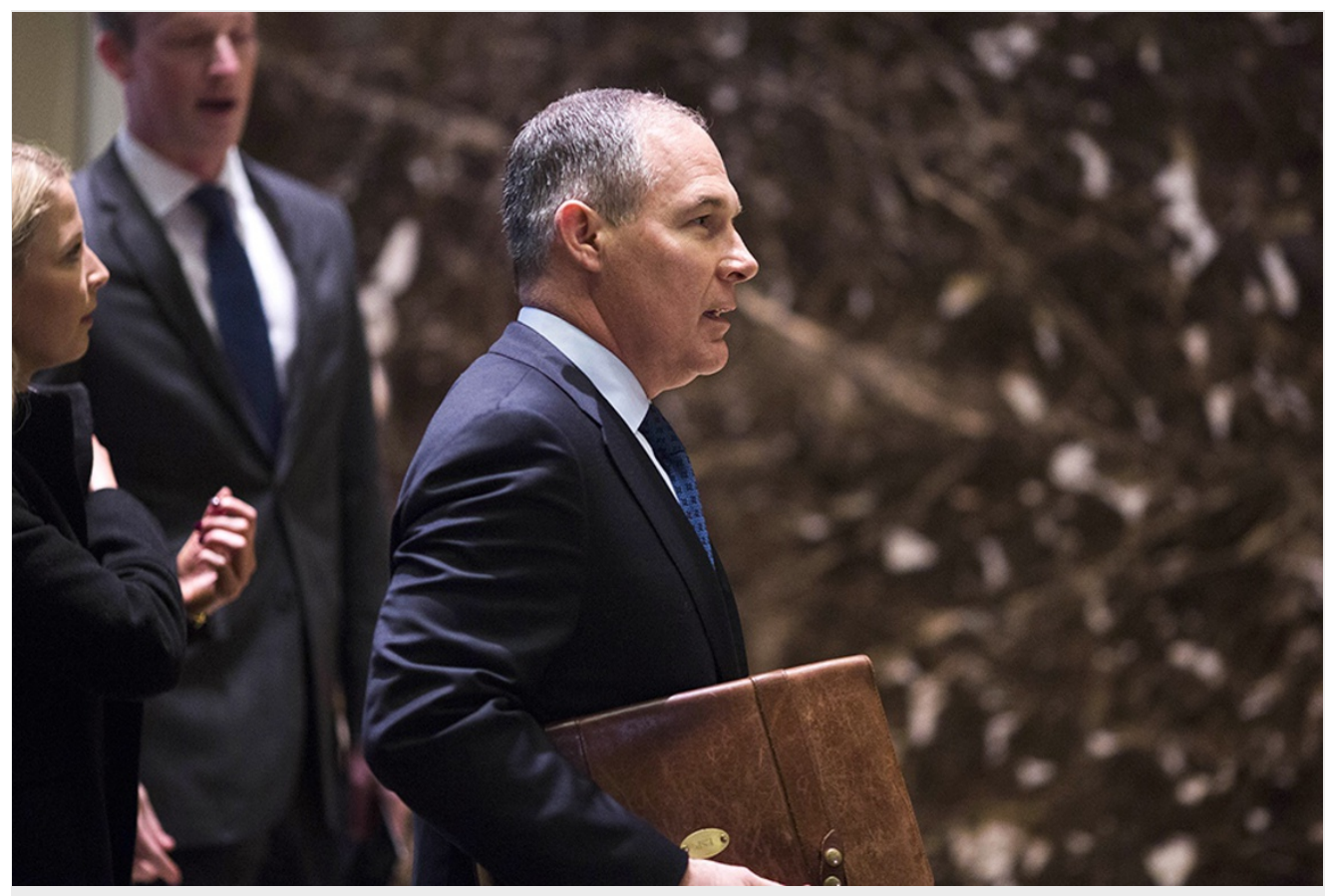

John Taggart/Bloomberg/Getty

Scott Pruitt has questioned the science underlying climate change.

President-elect Donald Trump has chosen Oklahoma attorney-general Scott Pruitt to lead the US Environmental Protection Agency (EPA).

Pruitt, who must be confirmed by the US Senate, is an ardent opponent of federal regulations to curb climate change and has questioned the science underlying global warming. He is one of dozens of state officials who have mounted a legal challenge to President Barack Obama's limits on greenhouse-gas emissions from power plants — regulations that Trump has promised to repeal.

That case is pending review by the US Supreme Court. If the court agrees to hear the case, the outcome could hinge on whom Trump nominates to fill a vacancy on the nine-member panel of judges. Some experts say that the EPA itself could also seek to repeal the regulations after Trump takes office.

In May, Pruitt made his views on climate science clear in a guest editorial in the National Review that he wrote with Alabama attorneygeneral Luther Strange. "Scientists continue to disagree about the degree and extent of global warming and its connection to the actions of mankind," the pair wrote. "That debate should be encouraged — in classrooms, public forums, and the halls of Congress. It should not be silenced with threats of prosecution. Dissent is not a crime."

\section{Strong reactions}

Environmentalists blasted Trump for choosing Pruitt, whom they say has put the interests of the fossil-fuel industry before those of the environment and the people of Oklahoma. As well as challenging Obama's climate regulations, Pruitt has sued the EPA to halt a series of regulations intended to keep air and water clean. In doing so, he has often worked in concert with the same oil, gas and coal companies that he would regulate as EPA chief. 
vice-president for climate and political affairs at the Environmental Defense Fund, an activist group in New York City. "It's an unprecedented gamble with an agency that has protected the air we breathe and the water we drink across Republican and Democratic administrations for more than 40 years."

But Pruitt will have plenty of support from industry officials - many of whom have long asserted that the EPA has overreached its regulatory authority, particularly on climate change.

Scott Segal, a lawyer at the firm Bracewell in Washington DC, which has represented many industry interests, calls Pruitt "a measured and articulate student of environmental law and policy". Segal adds that Pruitt understands and respects states' roles in environmental policy, and that his decisions to challenge federal regulations should not disqualify him for the EPA job.

"There is no conflict in faithfully representing your state on litigation dealing with rules of general applicability and then serving your nation as a federal administrative official," Segal says.

To win Senate approval for the EPA post, Pruitt would require only a simple majority of 51 senators in a body where Republicans will hold at least 51 seats. (A 52nd seat is up for grabs in a 10 December run-off election in Louisiana.) This means that Republicans should have enough votes to approve Pruitt if they stick together.

Nature | doi:10.1038/nature.2016.21127 